\title{
Evolution of mortality for colorectal cancer in Brazil and regions, by sex, 1996-2015
}

\author{
Viviane Gomes Parreira DUTRA ${ }^{1}$, Virgilio Augusto Gomes PARREIRA² and Raphael Mendonça GUIMARÃES ${ }^{3}$
}

Received 17/7/2017

Accepted 13/9/2017

\begin{abstract}
Background - Colorectal cancer is among the three most frequent neoplasms in Brazil, being a public health problem. Objective - To describe distribution pattern of colorectal cancer mortality in Brazil and regions, according to sex, between 1996 and 2015 . Methods - Values of standardized and stratified mortality rates by sex between 1996 and 2015 were used, through polynomial regression models and joinpoint analysis. Results - It was observed that, for linear trends in mortality rates, for both sexes, there is a statistically significant trend increasing in both models, with rates and trends, and higher for men than for women, respectively, $7.3 \%$ per year $\left(\mathrm{R}^{2}=0.95, P<0.001\right)$ and $6.5 \%$ per year $\left(\mathrm{R}^{2}=0.87, P<0.001\right)$. It is observed a difference in magnitude and behavior of trend between the regions. Conclusion - It is understood that it is important to know the trend of rates in order to define priority populations for early interventions that increase survival and reduce mortality.
\end{abstract}

HEADINGS - Colorectal neoplasms, mortality. Men. Women. Regression analysis. Colonic neoplasms. Time series studies.

\section{INTRODUCTION}

Colorectal cancer $(\mathrm{CRC})$ is the third most common cancer overallthe world among men, and second among women, accounting for about 1.4 million new cases in 2012, with 746,000 cases being diagnosed in men and 614,000 in women ${ }^{(1)}$. Most recent estimate of Brazilian National Cancer Institute (INCa) for 2016/2017 is that CRC will affect 16,660 men and 17,620 women, consisting of the third and second anatomical locations, respectively. Among Brazilian regions, Southeast region presented the highest standardized incidence of CRC among men $(24.27 / 100,000)$ and women $(22.66 / 100,000)$, and lowest standardized incidence rates were observed in North region, among men $(5.34 / 100,000)$ and women $(5.89 / 100,000)^{(2)}$

Regarding the distribution of mortality rates due to this type of cancer in Brazilian regions, studies showed a growing increase, especially in South and Southeast regions, which presented rates similar to those in highly industrialized countries ${ }^{(3-5)}$.

Even with advances in diagnosis and treatment, mortality due to this neoplasm remains high, so that its overall average survival over five years is reported to be around 55\% in developed countries and $40 \%$ in developing countries ${ }^{(6)}$.

Epidemiological knowledge about colorectal cancer mortality is important to support the planning of structured and effective public policies for early detection and treatment. In this sense, this study aimed to analyze temporal trend of CRC mortality in Brazil as a whole and in its main geographic regions, in the period between 1996 and 2015.

\section{METHODS}

This is a time-series study, whose unit of analysis was mortality rates for CRC in Brazil between 1996 and 2015. Data were obtained from Ministry of Health' Mortality Information System (SIM/ SUS). International Classification of Diseases (ICD) codes used were $\mathrm{C} 18, \mathrm{C} 19$ and $\mathrm{C} 20$ (which include all subcategories), referenced underlying cause of death at the 10th revision. For the calculation of mortality coefficients, the annual population estimates of Brazilian Institute of Geography and Statistics (IBGE) were used as the denominator, by sex, age group and region of residence, from 1996 to 2012. For the years between 2013 and 2015, estimation of population was calculated through intercensorial population projections, using geometric interpolation. It is worth mentioning that it was decided to make analysis by regions due to the marked inequality among them, especially among developed South and Southeast and, on the other hand, less developed North and Northeast.

Correction of deaths for CRC was performed through deaths from undefined causes (codes: R00-R99 from ICD-10). Considering that cancer death records are better stated than the other causes of death, it was assumed that representation of cancers among undefined causes is smaller, making a proportional redistribution of all deaths from undefined causes ${ }^{(7)}$. Thus, in order to avoid overestimation of the number of deaths, $50.0 \%$ of deaths were proportionally redistributed as corresponding to neoplasms, considering proportions by sex, age group and geographical area ${ }^{(8)}$. Crude mortality coefficients per 100,000 inhabitants were calculated and later standardized by the direct method using world population proposed by $\mathrm{Segi}^{(9)}$ and modified by Doll et al. ${ }^{(10)}$. Stationarity of the time series were evaluated through the Wald-Wolowitz test, and the trend effect were verified through the Cox-Stuart test.

After checking the effect, mortality trend was analyzed using polynomial regression technique ${ }^{(1)}$. Mortality coefficient from $\mathrm{CRC}$ was considered as a dependent variable (y), and year centered by midpoint of the period ( $\mathrm{x}-2005)$ was used as independent variable (x). Both linear, second and third degree regression models

Declared conflict of interest of all authors: none

Disclosure of funding: no funding received

This study was performed at: Fundação Oswaldo Cruz and Instituto Nacional de Câncer José Alencar Gomes Silva.

${ }^{1}$ Fundação Oswaldo Cruz. Instituto Nacional de Infectologia Evandro Chagas, Rio de Janeiro, RJ, Brasil; ${ }^{2}$ Instituto Nacional de Câncer José Alencar Gomes da Silva (INCA), Rio de Janeiro, RJ, Brasil; ${ }^{3}$ Fundação Oswaldo Cruz (Fiocruz), Rio de Janeiro, RJ, Brasil.

Correspondence: Raphael Mendonça Guimarães. Av. Brasil, 4365, Manguinhos - EPSJV/Fiocruz. CEP: 21040-360 - Rio de Janeiro, RJ, Brasil. E-mail: raphael.guimaraes@fiocruz.br 
were tested. Eligible model was the one that had the best fit of determinant coefficient $\left(\mathrm{R}^{2}\right)$, statistical significance (considering the $5 \%$ level of significance) and residue analysis. In cases where the models presented similarity, those who presented the simplest model were chosen (parsimony criteria). This analysis was performed using R program, version 3.4.1.

Additionaly, for joinpoint trend analysis, inflection point method was used to calculate both annual increase of mortality rates (annual percentage change - APC), and also the variation of the last 5 and 10 years (AAPC), which allows the adjustment of data into a serie from the lowest possible number of joinpoints (zero, ie, a line with no inflection points) and tests whether the inclusion of more joinpoints was statistically significant. Significance tests used were based on Monte Carlo permutation method, considering rates logarithm ${ }^{(12)}$.

Finally, according to Resolution 466/2012, from National Council of Ethics in Research, since this paper performed analysis from public data, it is not necessary to submit to local Ethics Commitee approval.

\section{RESULTS}

In Brazil, from 1996 to 2015, there were 201,075 deaths from colorectal cancer. Among these deaths, 140,753 (70.1\%) occurred in individuals aged 60 years or older. In this period, proportional mortality due to this type of cancer showed an increasing trend $\left(\mathrm{R}^{2}=0.92, P<0.001\right)$, ranging from $5.69 \%$ to $7.08 \%$. Median mortality rates are higher in South region and, when averages between regions for the period 1996 to 2015 are compared, they are different, with statistical significance $(P<0.001)$. Due to age group, median is higher for age group of 60 and over, and lower for the age group 20 to $39(P<0.001)$. Although tmedian mortality rate was higher for females, it did not present statistical significance $(P=0.341)$, showing no difference in mortality pattern due to sex.

When considering time series, we proceeded to diagnosis of randomness, in order to evaluate the assumption of non-stationary values (TABLE 1). Applying Wald-Wolfowitz test, we obtained a number of observation groups different from each region and sex. Through analysis of parameters of the series (variance and standard deviation), and the verification of statistical significance allowed to reject null hypothesis of randomness of the data, making possible the attempt to model the data.

In order to verify the effect of trend of mortality time rates series, Cox-Stuart test was performed. Series were analyzed by gender (male and female) and by location (Brazil and regions), and showed that linear trend was adequate, with coefficient of determination $\left(\mathrm{R}^{2}\right)$ ranging from 0.53 to 0.99 (TABLE 2). TABLE 3 presents adjusted models to all series through polynomial regression. For all Brazilian regions, the best fit for series was obtained with linear model. With regard to the trend of mortality by sex, according to region, it was observed that for both sexes in all regions, it was increasing and significant.

After observing the final adjustments, considering the joinpoint model, APC of mortality for CRC presented a difference between regions. However, when comparing joinpoint analysis and polynomial regression analysis, two points are relevant. The first point concerns the fact that there is no significant variation for any location and sex that would generate a point of inflection, so the trends are linear. However, the growth speed of North and Northeast regions is higher than in south and Southeast regions, although these last regions present higher mortality rates. Second
TABLE 1. Diagnosis of randomness of mortality time series for colorectal cancer in Brazil and large regions. Brazil, 1996-2015

\begin{tabular}{|c|c|c|c|c|c|c|c|c|c|}
\hline Local & $\mathbf{R}$ & $\mathbf{n}_{0}$ & $\mathrm{n}_{1}$ & $\mathrm{n}$ & $\mathrm{E}(\mathrm{R})$ & $\begin{array}{l}\text { Var } \\
\text { (R) }\end{array}$ & $\begin{array}{l}\text { SD } \\
\text { (R) }\end{array}$ & Z & $P$ value \\
\hline \multicolumn{10}{|l|}{ Brazil } \\
\hline Male & 2 & 8 & 10 & 18 & 9.89 & 4.11 & 2.04 & -3.88 & $<0.001$ \\
\hline Female & 2 & 7 & 11 & 18 & 9.56 & 3.9 & 1.93 & -3.87 & $<0.001$ \\
\hline Total & 2 & 7 & 11 & 18 & 9.56 & 3.8 & 1.95 & -3.87 & $<0.001$ \\
\hline \multicolumn{10}{|l|}{ Midwest } \\
\hline Male & 2 & 8 & 10 & 18 & 9.89 & 4.11 & 2.03 & -3.88 & $<0.001$ \\
\hline Female & 2 & 7 & 11 & 18 & 9.56 & 3.79 & 1.95 & -3.87 & $<0.001$ \\
\hline Total & 2 & 8 & 10 & 18 & 9.89 & 4.13 & 2.03 & -3.88 & $<0.001$ \\
\hline \multicolumn{10}{|l|}{ North } \\
\hline Male & 2 & 9 & 9 & 18 & 10 & 4.28 & 2.05 & -3.89 & 0.001 \\
\hline Female & 2 & 10 & 8 & 18 & 9.89 & 4.16 & 2.03 & -3.88 & $<0.001$ \\
\hline Total & 2 & 10 & 8 & 18 & 9.89 & 4.17 & 2.04 & -3.88 & $<0.001$ \\
\hline \multicolumn{10}{|l|}{ Northeast } \\
\hline Male & 2 & 9 & 9 & 18 & 10 & 4.26 & 2.06 & -3.89 & $<0.001$ \\
\hline Female & 2 & 8 & 10 & 18 & 9.89 & 4.15 & 2.03 & -3.88 & $<0.001$ \\
\hline Total & 2 & 8 & 10 & 18 & 9.89 & 4.19 & 2.03 & -3.88 & $<0.001$ \\
\hline \multicolumn{10}{|l|}{ South } \\
\hline Male & 4 & 10 & 8 & 18 & 9.89 & 4.10 & 2.03 & -2.9 & 0.002 \\
\hline Female & 4 & 9 & 9 & 18 & 10 & 4.23 & 2.06 & -2.92 & 0.002 \\
\hline Total & 4 & 8 & 10 & 18 & 9.89 & 4.14 & 2.03 & -2.9 & 0.002 \\
\hline \multicolumn{10}{|l|}{ Southeast } \\
\hline Male & 2 & 7 & 11 & 18 & 9.56 & 3.87 & 1.95 & -3.87 & $<0.001$ \\
\hline Female & 4 & 8 & 10 & 18 & 9.89 & 4.15 & 2.03 & -2.9 & 0.002 \\
\hline Total & 4 & 8 & 10 & 18 & 9.89 & 4.11 & 2.03 & -2.9 & 0.002 \\
\hline
\end{tabular}

$\mathrm{R}$ : number of observed groups; $\mathrm{n}_{0}$ : number of observations below average along the period; $\mathrm{n}_{1}$ : number of observations above average along the period; $\mathrm{n}$ : número total de observações da distribuição; E (R): average of number of observed groups; Var (R): variance of number of observed groups; SD (R): standard deviation of number of observed groups; Z: Wald's test.

TABLE 2. Parameters to verify trend effect of time series of mortality rates for colorectal cancer in Brazil and large regions by sex. Brazil, 1996-2015

\begin{tabular}{|c|c|c|c|c|c|c|c|c|}
\hline Local & $\boldsymbol{\beta}_{0}$ & $\boldsymbol{\beta}_{1}$ & $\mathrm{SE}_{\mathrm{res}}$ & $\mathrm{df}$ & $\mathbf{R}^{2}$ & F & Trend & $P$ value ${ }^{*}$ \\
\hline \multicolumn{9}{|l|}{ Brazil } \\
\hline Male & 5.64 & 0.16 & 0.15 & 16 & 0.97 & 484.5 & increase & $<0.001$ \\
\hline Female & 5.73 & 0.11 & 0.20 & 16 & 0.85 & 94.2 & increase & 0.002 \\
\hline Total & 5.69 & 0.12 & 0.18 & 16 & 0.92 & 205.2 & increase & 0.001 \\
\hline \multicolumn{9}{|l|}{ Midwest } \\
\hline Male & 4.24 & 0.22 & 0.20 & 16 & 0.96 & 442.2 & increase & $<0.001$ \\
\hline Female & 4.48 & 0.2 & 0.38 & 16 & 0.84 & 91.6 & increase & 0.003 \\
\hline Total & 4.37 & 0.19 & 0.27 & 16 & 0.93 & 211.5 & increase & $<0.001$ \\
\hline \multicolumn{9}{|l|}{ North } \\
\hline Male & 1.30 & 0.15 & 0.16 & 16 & 0.95 & 330.7 & increase & $<0.001$ \\
\hline Female & 2.40 & 0.1 & 0.24 & 16 & 0.68 & 36.9 & increase & 0.01 \\
\hline Total & 1.84 & 0.17 & 0.15 & 16 & 0.93 & 210.6 & increase & $<0.001$ \\
\hline \multicolumn{9}{|l|}{ Northeast } \\
\hline Male & 1.51 & 0.2 & 0.10 & 16 & 0.99 & 1186.0 & increase & $<0.001$ \\
\hline Female & 2.00 & 0.17 & 0.10 & 16 & 0.98 & 723.8 & increase & $<0.001$ \\
\hline Total & 1.77 & 0.17 & 0.09 & 16 & 0.99 & 1191.0 & increase & $<0.001$ \\
\hline \multicolumn{9}{|l|}{ South } \\
\hline Male & 7.95 & 0.19 & 0.36 & 16 & 0.87 & 116.2 & & 0.001 \\
\hline Female & 7.62 & 0.1 & 0.39 & 16 & 0.53 & 20.0 & & 0.03 \\
\hline Total & 7.77 & 0.13 & 0.36 & 16 & 0.76 & 55.5 & increase & 0.002 \\
\hline \multicolumn{9}{|l|}{ Southeast } \\
\hline Male & 8.08 & 0.18 & 0.20 & 16 & 0.94 & 248.0 & increase & $<0.001$ \\
\hline Female & 7.42 & 0.13 & 0.24 & 16 & 0.73 & 47.0 & increase & 0.008 \\
\hline Total & 7.56 & 0.17 & 0.22 & 16 & 0.87 & 114.5 & increase & 0.005 \\
\hline
\end{tabular}

$\beta_{0}$ : intercept; $\beta_{1}$ : coefficient; $\mathrm{SE}_{\mathrm{res}}$ : standard erro ror residual model.; df: degree of freedom; $\mathrm{R}^{2}$ : determination coefficient; F: test statistics; $* P$ value from Cox-Stuart test. 
TABLE 3. Regression models for colorectal cancer mortality coefficients, by sex and region. Brazil, 1996-2015

\begin{tabular}{lcccc}
\hline Sex/Region & Model & $\mathbf{R}^{2}$ & $\boldsymbol{P}$ value & Trend \\
\hline $\begin{array}{l}\text { Midwest } \\
\text { Male }\end{array}$ & $\mathrm{y}=6.09+0.18 \mathrm{x}$ & 0.96 & $<0.001$ & increase \\
Female & $\mathrm{y}=6.04+0.15 \mathrm{x}$ & 0.84 & $<0.001$ & increase \\
Total & $\mathrm{y}=6.07+0.16 \mathrm{x}$ & 0.93 & $<0.001$ & increase \\
Northeast & & & & \\
Male & $\mathrm{Y}=2.95+0.14 \mathrm{X}$ & 0.99 & $<0.001$ & increase \\
Female & $\mathrm{Y}=3.19+0.12 \mathrm{X}$ & 0.98 & $<0.001$ & increase \\
Total & $\mathrm{Y}=3.08+0.13 \mathrm{X}$ & 0.98 & $<0.001$ & increase \\
North & & & & \\
Male & $\mathrm{y}=2.54+0.12 \mathrm{X}$ & 0.94 & $<0.001$ & increase \\
Female & $\mathrm{y}=3.03+0.06 \mathrm{X}$ & 0.73 & $<0.001$ & increase \\
Total & $\mathrm{y}=2.78+0.09 \mathrm{X}$ & 0.92 & $<0.001$ & increase \\
Southeast & & & & \\
Male & $\mathrm{y}=9.46+0.13 \mathrm{x}$ & 0.93 & $<0.001$ & increase \\
Female & $\mathrm{y}=8.14+0.08 \mathrm{x}$ & 0.76 & $<0.001$ & increase \\
Total & $\mathrm{y}=8.57+0.12 \mathrm{x}$ & 0.89 & $<0.001$ & increase \\
South & & & & \\
Male & $\mathrm{y}=9.62+0.16 \mathrm{x}$ & 0.85 & $<0.001$ & increase \\
Female & $\mathrm{y}=8.38+0.09 \mathrm{x}$ & 0.58 & 0.001 & increase \\
Total & $\mathrm{y}=8.94+0.13 \mathrm{x}$ & 0.77 & $<0.001$ & increase \\
Brazil & & & & \\
Male & $\mathrm{y}=7.04+0.14 \mathrm{x}$ & 0.96 & $<0.001$ & increase \\
Female & $\mathrm{y}=6.56+0.08 \mathrm{x}$ & 0.84 & $<0.001$ & increase \\
Total & $\mathrm{y}=6.77+0.11 \mathrm{x}$ & 0.91 & $<0.001$ & increase \\
\hline
\end{tabular}

point refers to the fact that there is a little difference between APC values and polynomial regression parameters. This is due to the modeling difference, since polynomial regression performs modeling considering the terms in time, and uses the adjusted mortality rate as the outcome variable; on the other hand, joinpoint analysis performs modeling through a poisson-type distribution (TABLE 4).

\section{DISCUSSION}

Mortality rates for CRC tended to increase, in all Brazilian regions, for men and women throughout the period. In addition, results by joinpoint did not present inflections for the Brazilian regions. However, APC of specific mortality for CRC for males in North and Northeast regions was higher than in South and Southeast regions. These are the two less developed regions of the , where we found lowest mortality rates, but also present a different rate of increase than the other regions.

In fact, international estimates indicate that, in United States and other developed countries, mortality due to this neoplasm is declining; on the other hand, a number of developing and underdeveloped countries are on the increase ${ }^{(13)}$. In Europe, an overview of recent trends in mortality from neoplasias discussed there was a trend of increasing mortality from CRC for men and a reduction for women in Spain ${ }^{(14)}$. In Italy, researchers have shown a growing and statistically significant trend for men in the period 1978-2004 ${ }^{(15)}$. However, a study on mortality due to neoplasias carried out in European Union countries has observed a decrease in CRC mortality rates in both sexes ${ }^{(16)}$.
TABLE 4. Time trend estimates of specific mortality rates for colorectal cancer according to cut-off points obtained through joinpoint analysis. Brazil, 1996-2015

\begin{tabular}{|c|c|c|c|c|c|c|}
\hline \multirow{2}{*}{ Region } & \multirow{2}{*}{ Sex } & \multirow{2}{*}{ Period } & \multirow{2}{*}{ APC } & \multicolumn{2}{|c|}{$95 \% \mathrm{CI}$} & \multirow{2}{*}{$P$ value } \\
\hline & & & & LL & UL & \\
\hline \multirow{3}{*}{ North } & Total & 1996-2015 & 3.61 & 3.12 & 4.09 & $<0.001$ \\
\hline & Male & $1996-2015$ & 5.41 & 4.85 & 5.96 & $<0.001$ \\
\hline & Female & $1996-2015$ & 2.83 & 1.39 & 3.03 & $<0.001$ \\
\hline \multirow{3}{*}{ Northeast } & Total & $1996-2015$ & 4.65 & 4.37 & 4.95 & $<0.001$ \\
\hline & Male & $1996-2015$ & 5.41 & 5.04 & 5.78 & $<0.001$ \\
\hline & Female & $1996-2015$ & 4.09 & 3.77 & 4.38 & $<0.001$ \\
\hline \multirow{3}{*}{ Southeast } & Total & $1996-2015$ & 1.26 & 1.02 & 1.50 & 0.020 \\
\hline & Male & $1996-2015$ & 1.57 & 1.34 & 1.79 & 0.005 \\
\hline & Female & $1996-2015$ & 0.95 & 0.66 & 1.24 & 0.01 \\
\hline \multirow{3}{*}{ South } & Total & $1996-2015$ & 1.42 & 1.03 & 1.78 & 0.003 \\
\hline & Male & $1996-2015$ & 1.86 & 1.49 & 2.24 & 0.001 \\
\hline & Female & $1996-2015$ & 0.98 & 0.53 & 1.42 & 0.008 \\
\hline \multirow{3}{*}{ Midwest } & Total & $1996-2015$ & 3.07 & 2.59 & 3.56 & $<0.001$ \\
\hline & Male & $1996-2015$ & 3.31 & 2.95 & 3.68 & $<0.001$ \\
\hline & Female & $1996-2015$ & 2.87 & 2.21 & 3.53 & $<0.001$ \\
\hline \multirow{3}{*}{ Brazil } & Total & $1996-2015$ & 1.71 & 1.45 & 1.97 & 0.002 \\
\hline & Male & $1996-2015$ & 2.14 & 1.93 & 2.36 & $<0.001$ \\
\hline & Female & $1996-2015$ & 1.35 & 1.05 & 1.65 & $<0.001$ \\
\hline
\end{tabular}

APC: anual percentage change; CI: confidence interval; LL: lower limit; UL: upper limit

Several studies exploring the development context to explain the dynamics of incidence and mortality by specific cancers clearly demonstrate the direct association between the pattern of morbidity and mortality in this group and socioeconomic context. More recently, some findings show that, in 2008, the highest burden of cancer was in areas of very high HDI, which accounted for almost $40 \%$ of global incidence burden, despite accounting for only $15 \%$ of the world population; in areas with low HDI, the burden of cancer accounted for only $2 \%$ of the global burden of disease, with a population representing about $6 \%$ of global population. However, in projection for 2030, it's expected a largest absolute increase in areas with low $\mathrm{HDI}^{(17-19)}$.

In Brazil, National Cancer Care Policy is based on issues related to cancer incidence and mortality, nationally and universally. However, it is necessary to consider Brazilian regional differences in action planning, focusing on cancer care, considering decentralization of these actions to ensure their effectiveness. A study on the prediction of CRC mortality in Brazil and its geographic regions, until 2025, found that there will be an increase in mortality rates in this type of neoplasm, showing a greater magnitude in North, Northeast and Central West, which also correspond with the less developed areas of the country ${ }^{(20)}$.

It is important to mention that South and Southeast regions have the highest mortality due to CRC for both sexes, and these are the ones with the highest development in the country. It should be noted that these are the regions that have a concentration of health services, including those that make up the highly complex 
network $^{(21)}$. On the other hand, North region had the lowest mortality rate due to this type of neoplasm in relation to the others, followed by Northeast and Central West regions.

Several authors have discussed regional heterogeneity of mortality rates from $\mathrm{CRC}^{(3-5)}$ and these differences may be related to lifestyle, eating habits and socioeconomic status, and as access to health services and the quality of medical care as well. For example, in a study carried out in Fortaleza and Porto Alegre, two Brazilian capitals located respectively in Northeast and South regions of country, to analyze the trend of incidence rates and distribution pattern of $\mathrm{CRC}$, found that incidence mean rates were about three times higher in Porto Alegre than in Fortaleza, for both men and women. Authors considered that access to diagnostic and therapeutic services (public and private) may be one of the explanations for this result, since in this period Porto Alegre had six highly complex cancer care services, while in Fortaleza there was a hospital reference ${ }^{(22)}$.

Data from the last Family Budgets Survey (Pesquisa de Orçamentos Familiares - POF) pointed to regional differences relevant to the pattern of Brazilian diet. South region had the lowest percentage of the country consuming cereals, vegetables and oilseeds $(5.5 \%)$, while the highest percentage occurred in Northeast $(10.3 \%)$ and Central West $(10.2 \%)$. Southeast region had the highest percentage of meat and processed food consumption (3.5\%), equivalent to twice that found in Northeast region $(1.7 \%)^{(23)}$. Regarding the dietary pattern, it is known that tfruit and vegetables consumption is still much lower than recommended by World Health Organization, and the study of the trend does not show an increase over the last years. Also, this deficiency in macronutrient food intake of protective effect against cancer is differentiated by income, so that low-income families experience a lower quality food pattern ${ }^{(24)}$.

In October 2015, scientists from ten countries met at International Agency for Research on Cancer (IARC), and concluded, after reviewing more than 800 published studies worldwide, on the carcinogenicity of red meat and processed meat consumption ${ }^{(25)}$. Therefore, consumption patterns should be considered in the evaluation of differences found in CRC mortality rates between regions and Brazilians, since South and Southeast regions, when compared to the others, present lifestyles that could lead to a higher risk of developing this type of cancer, such as low fiber intake and high dietary lipid content, high alcohol intake, higher prevalence of smoking, and high red meat consumption ${ }^{(26)}$. Considering the heterogeneity within Brazil, CRC lethality trend is still unclear, since survival depends mainly on access to early diagnosis and appropriate treatment in a timely manner. However, it is known that an experience of having cancer motivates people to change their lifestyle, especially those related to physical activity and healthy eating ${ }^{(27)}$.

Relationship between socioeconomic level and colorectal is known in literature ${ }^{(28)}$. In a study carried out to estimate correlation between per capita income and the CRC mortality rate in Brazil from 2001 to 2009 , there was a positive and statistically significant correlation between more developed regions and the mortality rates both sexes ${ }^{(29)}$.

Several epidemiological studies have shown that prevention programs have been effective in decreasing mortality and incidence of $\mathrm{CRC}$, but even with these findings, in countries with abundant resources, such as United States, adherence remains low, influencing cost-effectiveness of programs ${ }^{(30,31)}$. In Brazil, National Policy on Oncological Care (PNAO) - promotion, prevention, diagnosis, treatment, rehabilitation and palliative care was instituted through the Ministerial Cabinet Order No. 2,439 of $2005^{(32)}$. Ministry of Health still does not consider if implementation of population screening programs for CRC is currently effective, and it is recommended as an early diagnosis strategy the widespread dissemination of warning signs to the population and health professionals, immediate access to diagnostic procedures and appropriate and timely treatment ${ }^{(33)}$. In this sense, it should be ratified that recent meta-analysis confirmed that faecal occult blood research, fecal immunohistochemistry, sigmoidoscopy and colonoscopy are all effective in preventing CRC deaths, especially if combined, reducing the incidence of deaths by up to $59 \%$. However, it suggests that colonoscopy is the most effective screening method to prevent CRC deaths ${ }^{(34)}$. Also, despite of dietary factors evaluated in population attributable fraction ${ }^{(35)}$, there is a growing tendency to consider the association between human papillomavirus (HPV) and $\mathrm{CRC}^{(36)}$. Since it is one of the most common sexually transmitted diseases and the association with the incidence of this type of cancer, the importance of the early diagnosis of oncogenic HPV infection is now discussed for prevention of new cases.

Limitations of this study may be related to the study design, not allowing inference of results at individual level and the use of secondary data. Using of mortality data from Mortality Information System may be related to sub-registries of deaths due to cancer, being able to present errors in the codifications of basic cause of death, and underestimation of mortality rates can be generated by classification of deaths as causes undefined or not specified in the death certificates.

\section{CONCLUSION}

Since CRC has implications for the possibilities of screening, diagnosis and treatment, as well as measures to promote health of population, not only with clinical approaches, it could be said that it represents an important public health problem in Brazil, showing a growing and statistically significant trend of mortality in Brazil and its regions over the last 20 years. Despite advances in public policies for cancer care, it is necessary to strengthen health surveillance, in order to subsidize preventive policies for the formulation of screening programs and early diagnosis, considering that prognosis of CRC is often poor when detected at a symptomatic stage. In this sense, those guidelines aim at reduction of long hospitalizations, high cost of treatment, rehabilitation and high mortality rates. It is worth mentioning, however, that in order to further discuss this measure, it is necessary to conduct cost-effectiveness studies applied to Brazilian context.

\section{Authors' contributions}

All authors contributed to article design; bibliographic research, data analysis and interpretation, discussion of results; writing and final approval of the article. 
Dutra VGP, Parreira VAG, Guimarães RM. Evolução da mortalidade por câncer de cólon e reto no Brasil e regiões, 1995 a 2015. Arq Gastroenterol. 2018;55(1):61-5.

RESUMO - Contexto - O câncer de cólon e reto está entre as três neoplasias mais frequentes no Brasil, sendo um problema de saúde pública. Objetivo - Descrever o padrão de distribuição da mortalidade por câncer de cólon e reto no Brasil e regiões, por sexo, no período de 1996 a 2015 . Métodos Utilizou-se os valores de taxas de mortalidade padronizadas e estratificadas por sexo entre 1996 e 2015, através dos modelos de regressão polinomial e análise por joinpoints. Resultados - Foi observado que, para as tendências lineares das taxas de mortalidade, para ambos os sexos, há tendência de aumento linear estatisticamente significativa em ambos os modelos, sendo as taxas e as tendências maiores para homens do que para mulheres, respectivamente, $7,3 \%$ ao ano $(\mathrm{R} 2=0,95 ; P<0,001)$ e $6,5 \%$ ao ano ( $2=0,87 ; P<0,001)$. Observa-se diferença na magnitude e comportamento da tendência entre as regiões. Conclusão - Entende-se que é importante conhecer a tendência das taxas de forma a definir populações prioritárias para intervenções precoces que aumentem a sobrevida e reduzam a mortalidade.

DESCRITORES - Neoplasias colorretais, mortalidade. Homens. Mulheres. Análise de regressão. Neoplasia do colo. Estudos de séries temporais.

\section{REFERENCES}

1. Ferlay J, Soerjomataram I, Ervik M, Dikshit R, Eser S, Mathers C, Rebelo M, Parkin DM, Forman D, Bray, F. GLOBOCAN 2012 v1.0. Cancer Incidence and Mortality Worldwide: IARC Cancer Base No. 11. Lyon, France: International Agency for Research on Cancer; 2014

2. Instituto Nacional de Câncer. Estimativa 2016: Incidência de Câncer no Brasil. Rio de Janeiro: Instituto Nacional de Câncer; 2015.

3. das Neves FJ, Mattos IE, Koifman RJ. Colon and rectal cancer mortality in Brazilian capitals, 1980-1997. Arq Gastroenterol. 2005;42:63-70.

4. Azevedo e Silva GA, Gamarra CJ, Girianelli VR, Valente JG. Cancer mortality trends in Brazilian state capitals and other municipalities between 1980 and 2006. Rev Saúde Pública. 2011;45:1009-18.

5. Vasques ALR, Peres MA. Time Trends in Colon and Rectal Cancer Mortality in the State of Santa Catarina, Brazil Between 1980 and 2006. Epidemiol. Serv. Saúde. 2010;19:91-100.

6. American Cancer Society. Colorectal Cancer Facts \& Figures 2014-2016. Atlanta, Ga: American Cancer Society; 2014.

7. Mello Jorge MH, Gotlieb SLD, Laurenti R. O sistema de informações sobre mortalidade: problemas e propostas para o seu enfrentamento I-mortes por causas naturais. Rev Bras Epidemiol. 2002;5:197-211.

8. Gamarra CJ, Valente JG, Mendonça GAS. Correção da magnitude da mortalidade por câncer do colo do útero no Brasil, 1996-2005. Rev Saúde Pública. 2010;44:629-38.

9. Segi M, Fujisaku S, Kurihara M, Narai Y, Sasajima K. The age-adjusted death rates for malignant neoplasms in some selected sites in 23 countries in 1954-1955 and their geographical correlation. Tohoku J Exp Med. 1960;72:91-103.

10. Doll R, Waterhouse J, Payne P. Cancer incidence in five continents: a technical report. Berlin: International Agency for Research on Cancer; 1966.

11. Latorre MRDO, Cardoso MRA. Análise de séries temporais em epidemiologia: uma introdução sobre os aspectos metodológicos. Rev Bras Epidemiol. 2001;4:145-52.

12. Kim HJ, Fay MP, Feuer EJ, Midthune DN. Permutation tests for Joinpoint regression with applications to cancer rates. Statistics in Medicine. 2000;19:335-51.

13. Thun MJ, DeLancey JO, Center MM, Jemal A, Ward EM. The global burden of cancer: priorities for prevention. Carcinogenesis. 2010;31:100-10.

14. Karim-Kos HE, de Vries E, Soerjomataram I, Lemmens V, Siesling S, Coebergh JW. Recent trends of cancer in Europe: a combined approach of incidence, survival and mortality for 17 cancer sites since the 1990s. Eur J Cancer. 2008;44:1345-89.

15. Stracci F, Canosa A, Minelli L, Petrinelli AM, Cassetti T, Romagnoli C, et al. Cancer mortality trends in the Umbria region of Italy 1978-2004: a Joinpoint regression analysis. BMC Cancer. 2007;16:7-10.

16. La Vecchia C, Bosetti C, Lucchini F, Bertuccio P, Negri E, Boyle P, et al. Cancer mortality in Europe, 2000-2004, and an overview of trends since 1975. Ann Oncol. 2010;21:1323-60

17. Clegg LX, Reichman ME, Miller BA, Hankey BF, Singh GK, Lin YD, et al Impact of socioeconomic status on cancer incidence and stage at diagnosis: selected findings from the surveillance, epidemiology, and end results: National Longitudinal Mortality Study. Cancer Causes Control. 2009;20:417-35.

18. Bray F, Jemal A, Grey N, Ferlay J, Forman D. Global cancer transitions according to the Human Development Index (2008-2030): a population-based study. Lancet Oncology. 2012;13:790-801.

19. Ward E, Cokkinides V, Singh GK, Cardinez C, Ghafoor A, Thun M. Cancer disparities by race/ethnicity and socioeconomic status. CA Cancer J Clin. 2004;54:78-93.
20. Souza DLB, Jerez-Roig J, Cabral FJ, De Lima JRF, Rutalira MK, Costa JAG. Colorectal Cancer Mortality in Brazil: Predictions Until the Year 2025 and Cancer Control Implications. Dis Colon Rectum. 2014;57:1082-9

21. Instituto Brasileiro de Geografia e Estatística. Pesquisa de Orçamentos Familiares 2008-2009: Despesas, Rendimentos e Condições de Vida. Rio de Janeiro: Instituto Brasileiro de Geografia e Estatística, 2010.

22. Reis RS, Santos MO, Bloch KV. Colorectal cancer in Porto Alegre and Fortaleza, Brazil: incidence trends and distribution pattern from 1990 to 1999. Cad. Saúde Pública. 2009;25:1046-53.

23. Instituto Brasileiro de Geografia e Estatística (IBGE). Pesquisa de orçamentos familiares 2008-2009: despesas, rendimentos e condições de vida. Rio de Janeiro: IBGE, 2010b.

24. Gomes FS, Silva GA., castro IRR. Aquisição domiciliar de refrigerantes e de biscoitos reduz o efeito de uma intervenção de promoção de frutas e hortaliças. Cad. Saúde Pública. 2017;33:e00023316.

25. International Agency for Research on Cancer. Consumption of red meat and processed meat. International Agency for Research on Cancer 114: Working Group. Lyon, IARC, 2015.

26. You YN, Xing Y, Feig BW, Chang GJ, Cormier JN. Young-onset colorectal cancer: is it time to pay attention? Arch Intern Med. 2012;172:287-9.

27. Silva GA, Rezende LFM, Gomes FS, Souza Júnior PRB, Szwarcwald CL, Eluf Neto J. Modos de vida entre pessoas que tiveram câncer no Brasil em 2013. Ciênc. Saúde Coletiva. 2016;21:379-88.

28. Sánchez-Barriga JJ. Mortality trends and risk of dying from colorectal cancer in the seven socioeconomic regions of Mexico, 2000-2012. Revista de Gastroenterología de México. 2017;82:217-25.

29. Guimarães RM, Rocha PG, Muzi CD, Ramos R de S. Increase income and mortality of colorectal cancer in Brazil, 2001-2009. Arq Gastroenterol. 2014;50:64-9.

30. Lansdorp-Vogelaar I, Knudsen AB, Brenner H. Cost-effectiveness of Colorectal Cancer Screening. Epidemiol Rev. 2011;33:88-100.

31. Chen C, Stock C, Hoffmeister M, Brenner H. Public health impact of colonoscopy use on colorectal cancer mortality in Germany and the United States. Gastrointest Endosc. 2017. pii: S0016-5107(17)31807-2.

32. Brasil. Ministério da Saúde. Portaria n. 2.439, de dezembro de 2005. Institui a Política Nacional de Atenção Oncológica: promoção, prevenção, diagnóstico, tratamento, reabilitação e cuidados paliativos, a ser implantada em todas as unidades federadas, respeitadas as competências das três esferas de gestão. Diário Oficial da União, Brasília, 8 dez 2005. Seção 1.

33. Brasil. Ministério da Saúde. Secretaria de Atenção à Saúde. Departamento de Atenção Básica. Rastreamento / Ministério da Saúde, Secretaria de Atenção à Saúde, Departamento de Atenção Básica. Brasília: Ministério da Saúde, 2010.

34. Zhang J, Cheng Z, Ma Y, He C, Lu Y, Zhao Y, et al. Effectiveness of Screening Modalities in Colorectal Cancer: A Network Meta-Analysis. Clin Colorectal Cancer. 2017. pii: S1533-0028(16)30157-8.

35. Azevedo e Silva G, de Moura L, Curado MP, Gomes Fda S, Otero U, Rezende LF, et al. The fraction of cancer attributable to ways of life, infections, occupation, and environmental agents in Brazil in 2020. PLoS One. 2016;11:e0148761.

36. Pelizzer T, Dias CP, PoetaI J, Torrianil T, Roncada C. Prevalência de câncer colorretal associado ao papilomavírus humano: uma revisão sistemática com metanálise. Rev. Bras. Epidemiol. 2016;1:791-802. 